\title{
Analyzing Economic Empowerment Of Women Entrepreneurs In Informal Sector
}

\author{
Seema Manzoor \\ \& \\ Asma Manzoor \\ Women's Studies \\ University of Karachi \\ Misbah B. Qureshi \\ Institute of Gender Studies \\ Sindh University Jamshoro
}

\begin{abstract}
This study aims to examine the involvement of women in the informal sector and accommodating them in their work. In past few decades women's economic role has been strongly recognized, though they are still marginalized by the society. Many social and cultural barriers restrain them from gaining their due status. In developing countries people are living below poverty line and among them women suffer more. Many social factors like class differences, gender discrimination and other factors reduced their efficiency. Therefore, there is a need to empower women in real sense and incorporate them in the mainstream. In developing countries women are major contributors in informal sector, i.e. they are backbone to national economy. In this study both quantitative method is used. Interview schedule is used as a tool for data collection having open ended and close ended questions. Data is represented by tabulation providing the statistical facts and figures. Non-probability sampling technique is applied to collect data and the Sample size is 100 includes women ( 25 women respondents from selected four different areas of Karachi city) who are involved in entrepreneurship. The purposive and convenience sampling techniques are used to collect date. Four areas of Karachi Metropolitan city are selected as the area of universe for the research, which are Shah Faisal colony, Gulshan-e-Iqbal, F. B. Area and North Karachi. Women entrepreneurs are involved in informal sector due to many factors like poverty, growing inflation, to support family and increasing family income.
\end{abstract}

Keywords: Women Entrepreneurs, Economic Empowerment, Informal Sector.

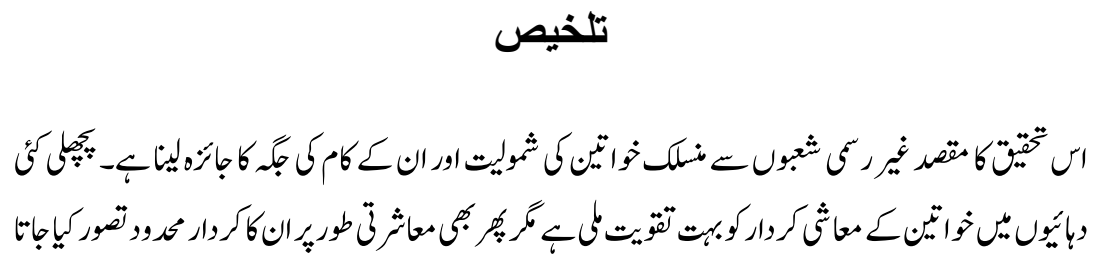




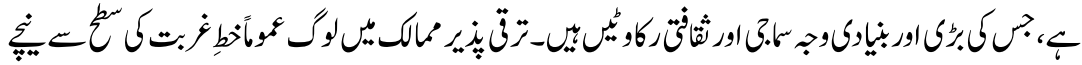

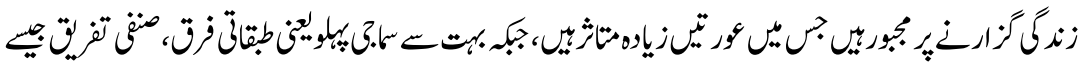

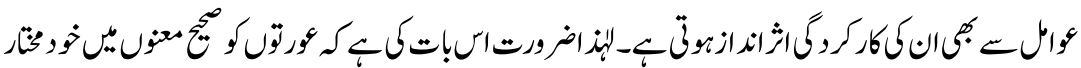

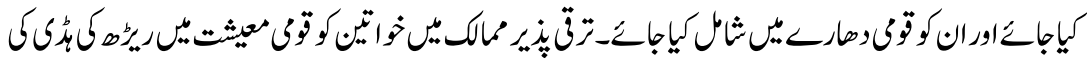

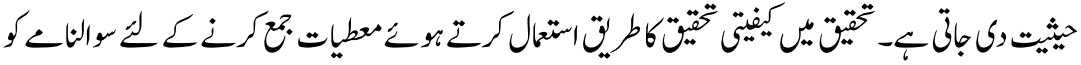

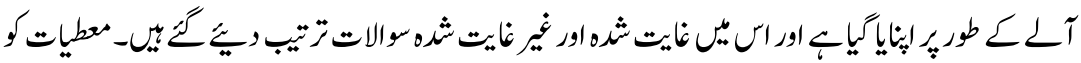

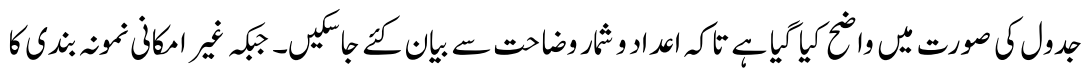

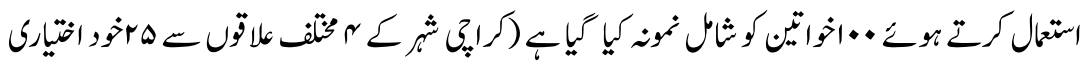

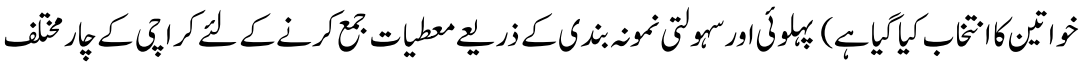

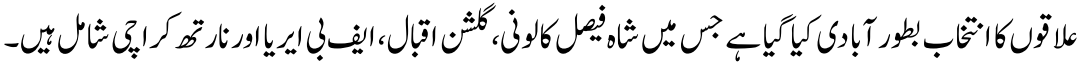

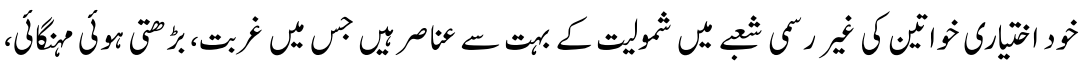

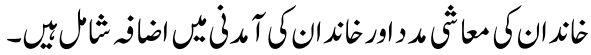

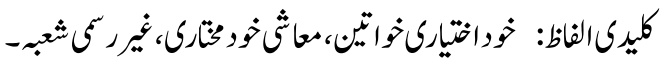

\section{Introduction}

Economic and political empowerment of women has become a focal point since last thirty years. Though efforts are made to improve women's status but still our social setup has restricted women from gaining their deserved status that is, at local and national level several cultural constraints are hampering their way to empowerment. People in developing countries are living below the poverty line and have no access to practical gender needs and strategic gender needs including basic necessities along with employment, equality, justice (Leonard, 2006). Class difference and unequal distribution of power has reduced their efficiency and working capacity also. In developing nations issues like generating income, attainment of power in public and private sector and political participation have become major barriers in acquiring empowerment. Governments have formulated policies but failed to implement them in order to get better results. Therefore, vulnerable people especially women are unable to gain access to their rights (Chatterjee \& Sheoran 2007). Women are backbone to national economy through informal sector but they remain unnoticed and unrecognized. Their contribution in informal work is not considered important such as in paid domestic work, working per piece from home or in factories, working as helper in family business. Due to these issues they face problems regarding employment status, 
low access to security, limited mobility and limited access to human rights and labour laws globally (Chant \& Pedwell, 2008).

Developing countries shows the tendency that women have greater contribution in informal sector as compared to men. The trend shows that more than $60 \%$ women are engaged in informal sector (other than agriculture), but is Asia the ratio of men and women seems equal, that is they both are almost equally making money through economic activities in informal sector (ILO, 2002). Informal sector is based on economic activities, which includes self-employed work and wage-employment, though it is an income producing enterprise but still it has no legal cover, regulations, recognition under government banner and has no regulatory or legal framework regarding protection. People especially women, engage in both self-employed work or wage work claims that they have no legal protection or security (Maxwell \& Armar-Klemesu, 2000). And they are not provided any platform to represent their work, to get social protection and to raise their voice on their issues. They have to take measures to protect their work and their business on their own. These deprived entrepreneurs have many issues which cannot be resolved without the intervention of government; therefore, it is the responsibility of government to bring all such enterprises under legal banner to secure them and to increase the productive role of people engaged in informal sector, because this is way to increase national economic growth. In past few decades, many researchers have identified that there is a strong connection between feminization of informal sector and feminization of poverty (Farah, 2009). As in developing nations people are living below the poverty line and are forced to be the part of informal economy to meet their family needs without getting and protection or benefits (Sudarshan \& Sinha, 2011). It is an established fact that women are dominant in informal sector and are major contributors as compared to men, Saigol (2010) and among these entrepreneur women mostly are home-based-workers (HNSA, 2014).

According to researches the increasing trend and participation of women entrepreneurs' in informal economy has many reasons behind it, among which the most common reasons are inflation and gender inequality and it is their compulsion to earn for their family. A survey conducted in 2010 by Pakistan Poverty Reduction Strategy Paper indicated that almost 75\% of Pakistan's population has very poor living i.e. they are living below the poverty line. Women being the soft target of gender discrimination and social exclusion are bound to do low paid work, usually they work as self-employed. Their low wage is due to illiteracy, less skills, lack of access to resources and above all they are unaware of the new market trends (Doane, 2007). Therefore, they are dependent on middleman and their contractors for raw material, and selling their finished products, which leads to exploitation and harassment. These women cannot even complain at any forum as they have no social or legal security. The issues they 
face during their economic activities are less chances of development, low wages or less profit, lack of capital and resources (Sudharshan \& Jhabyala, 2006). Many economic scholars are convinced and argue that women are the major contributors in economic growth in formal as well as in informal sectors (Mbeche, 2010).

In developing countries women face many issues, since public sector is not given due importance and is not potentially developed (Ghosh, 2015). Instead of incorporating women in economic sector and making appropriate policies to facilitate them, they are marginalized and face barriers in work. In developing countries the development procedures become too long and less viable, therefore, fails to accommodate local women in development process. Women of developing countries face several challenges already in their domestic domain, but the situation become more intense when they face problems while working in informal sector (Stromquist, 2014). These multi-faceted challenges adds more troubles for female entrepreneurs which includes temporary jobs, less profit margin, low wages, lack of social security and social benefits, poor and hazardous working conditions, less opportunities of upgrading skills and harassment.

In Pakistan rural women are supposed to look after domestic affairs which includes household chores, helping males in agrarian sector, rearing and bearing children etc. whereas, in urban areas women put their possible efforts to contribute their part in family income somehow (Hindman, 2015). To generate income they either do jobs in public or private sphere, but still due to male domination and stereotypical mindset women are confined to their houses, therefore, they usually perform their economic activities from home. Under such circumstances women entrepreneurship seems to be a fantasy not a reality, through which women can gain economic empowerment, but still it is seen that women's economic participation is increasing day by day. Even with these social and cultural constraints women's economic contribution is increasing. And the substantial increase is due to many reasons like death of husband or father, sickness in family, divorce or separation between husband and wife.

In Pakistan usually unmarried young female are also engaged in informal work by choice due to their needs or to support family (Mahtab, 2018). As females from middle class family have great concern for their family and they want to fulfill their family's needs. On the other hand they earn for their family for improving the standard of living. Family is their first priority, and for this reason they get engage in various entrepreneurial activities even if their health and life is at stake. Their health is badly affected and even they face psychological issues due to work load and stress which might lead to severe depression or anxiety. These women have number of challenges to face at work place and in their family and community. Harassment at work place is an issue which has very bad impact on women psyche. Due to low self-esteem, lesser skills, loss of family member or friends, character assassination and many other issues, life of women has become 
miserable in developing nations. With these issues economic problems have worsen the situation.

\section{Research Questions}

1. How women entrepreneurs can be recognized in informal sector for economic empowerment?

2. What policies should be designed to enhance the role of women in national economy?

\section{Objectives}

1. To find out how women can be empowered economically.

2. To find out if women are less paid than men in the informal sector.

3. To find out if women are aware about the policies and laws regarding women's economic empowerment.

4. To find out what household expenses are fulfilled by women working in the informal sector.

5. To find out how triple burden effects women's health and family life

\section{Theoretical Framework}

As per economic theories empowerment is linked with power relations. The term power should be considered as "power within" i.e. the self confidence level among workers, and "power with" i.e. the capacity to manage and work with others to gain common goals. This indicates that power should be used as to bring change and to take proper decisions and not to over-power others (Reeves and Baden, 2000). Thus empowerment relates to make right choices and to shape the available opportunities and offers. Regarding these aspect four different levels can be taken under consideration, which includes: 1) women's rights, and gaining access to resources and opportunities on human, and intellectual grounds, 2) to deal cultural values and norms, discriminatory ideologies and practices in order to remove the barriers for women in the patriarchal societies. 3) It is the most important step because it deals with the appropriate laws and policies for effective implication, 4) the fourth level encompasses the level of awareness, consciousness, information and work commitment. These levels can be achieved only by positive attitude to gain gender equality through long term planning and strategies. Implementation of policies alone cannot be effective, for that, women themselves have to raise their awareness level by all means to become agents of change (Organisation de coopération et de développement économiques, 2012).

Konayuma (2007) has stated that Zambian women do not have access to loan facilities and the negative attitude of society has restricted their economic 
activities. According to him, this situation is due to the less market exposure of Zambian women and this affects their national economy directly. Men are more socialized than women thus, leaving women handicapped regarding the characteristics of leadership, in decision making and empowerment (ILO, 2003). Since women do not have access to education therefore, they lack in socialization and gaining experience of work (Richardson and Finnegan, 2004).

\section{Review of Literature}

Women's contribution in the workforce is increasing overtime in the world economy. This increasing number of women in work is due to the many factors such as; Growing urbanization, unemployment, marketing competition and wage differences. Wage rates in informal sector is relatively low than formal sector. Women take over the informal economy. Almost $70 \%$ of women are working in Informal sector below the minimum wages. It is observed there is variation in conditions and wages in small factories and home-based workers. Women play a very vital role in strengthening the economy on international level in the informal sector. In the developing countries like Latin America and the Caribbean countries informal sector is a main source of providing employment to their people (males and females) whereas, in Venezuela and Argentina men are more active in this sector than women. The ratio of women workers in the informal sector is fairly high in the developing nations like the Dominican Republic and Paraguay and Brazil. According to the ILO, the women workers in the informal sector are seen in huge numbers (ILO, 2013).

Many studies have found the determinants of women's participation in informal sector. Mass of women runs their small business from their homes, streets and weekly markets and more involved in other sort of work. Women are inclined to do low income jobs as compare to men. The reason to engage of women in the informal sector is to earn for living and income generating. It may be due to the lack of skills, lack of experience and inexperience and illiteracy (Chen, 2011). Women in informal sector work as home-based workers, piece rate workers, selfemployed, unpaid workers in family business, seasonal workers, and subcontractors to formal enterprises (Mohapatra, 2012). According to Khan and Khan (2009) women do work for the family survival either work in formal and informal sector. They argued that women do much more work in informal sector for supporting their household and family as they find work certainly. The reason is they have large families, poverty and low status of education. Hence they involve in income generating activities. The lower income and poverty is due to the unemployment and less skill and education of husband meanwhile married women are more involved in the work for meets of household. 
Many countries do not have appropriate laws and policy to protect and enhance the informal economy and women's participation of work as well as women's in informal sector. The policy makers, governments and commandments are failed to address the situations and problems of women and gender discrimination. This shows lack of concern about women issues; hence women suffer all abuses in all sectors (Mwaba, 2010). According to Mohapatra (2012) in India, 96\% of females are working in informal sector than men. A large proportion of informal workers engage in urban informal sector are the migrants of rural areas and countryside for earning. They are employed in less skilled and unskilled jobs at low paying jobs. Long working hours, unfavorable working conditions and no benefits about job security is provided. It will be a challenge to ensure job security and safe working conditions in informal sector but to meet future needs increasing the employment opportunities in formal sector is also a challenge. These women are at high risk of health and have no access to health services. Their socio-economic status is very low. Low health status, no access to resources, social and class differences are facing by women workers. Women workers contribute more in unorganized sector for compete the existing patriarchal structure and social norms. Women should provide control over resources, successful programs to enhance their skills and develop confidents. In addition they should also be empowered by giving trainings so that could fight against discriminatory social norms and generate new business by recognizing their status (Ramani et.al, 2013).

In informal economy of Pakistan $72 \%$ of women work in informal sector and $8 \%$ work in informally outside the informal sector that is formal sector (ILO 2013). It is argued by Hasan and Farooq (2015) Women face numerous problems and gender based in nature. Both men and women face different risk factors and affected differently by these factors. Home-based women workers are the part of social structure and their issues are rooted in socio cultural and economic patterns. Both men and women require policy in association with their gendered needs and identity. Women workers face feminization of poverty is substantial part of informal economy. They argued that these situations identify the need of gender specific policies to determine their problems, vulnerability and risks face by these women. The development programs should be trickle down to empower women. Women involve in informal sector are contributing in the national economy. The study found that gender discrimination is the prior feature which oppresses the women workers which requires gender norms and gender specific policies while formulating (Hasan \& Farooq, 2015).

Circumstances of women and her work are not favourable in informal sector globally. They are highly participated at low paid in unhealthy environment. Apart from agriculture, females work much more than males as well in different sectors of informal economy such as women with small scale business, family business, domestic workers, home based work, street vendors and self-employed. A 
considerable number of women are working voluntary in agriculture on the family farms. Women do unpaid household in long hours. These conditions originate division of labour in which women are confined to home-based employment where they earn less. In some countries here women work as hawkers, market and street vendors face high risk of violence and health. Child care and household make their work worsen as well as they suffer triple burden of work. They cannot access to childcare centre hence they bring their children at their workplace and sometimes dependent to their family members and neighbors for child care. In both developed and developing countries women work to support their families even with low earnings and unhealthy environment and uncertain nature of paid informal work (Bertulfo, 2011).

\section{Methodology}

The study will examine the women's involvement in informal sector and accommodating them in their work. The quantitative research method is used in this study. Survey method is proceeded to collect data. Data is administered by interview schedule and analyzed by using open ended and close ended questions. Semi-structured questionnaire as a tool for data collection and it was constructed in urdu language for the conv ince of respondents and it contains 85 questions in total to represent the absolute data. Non-probability sampling technique is applied for the selection of sample from universe and the Sample size is 100 , which includes women ( 25 respondents from selected four different areas of Karachi city) who are involved in entrepreneurship. The purposive and convenience sampling techniques are used to collect date with ease to save time and cost. Karachi Metropolitan city is the area of universe for the research; it is a largest city of Pakistan. It is an industrial Hub of the country. Therefore, using the above mentioned sampling techniques the universe for this study is selected as Shah Faisal colony, Gulshan-e-Iqbal, F. B. Area and North Karachi.

\section{Results and Discussion}

People migrate from one place to another in search of income generation and raising the standard of living. Migration is not a new phenomenon, but it is triggered with the increase in population and unequal distribution of resources. Though migration is very common, but its outcome is not same for everyone. Memon (2006) claims that, internal migration is a very important issue to address, because it reflects the gap between social classes and lack of policies and research on the vary topic. According to the UNESCO, migrants are not included in the societal face in terms of economy, culture, politics and social aspects. They suffer and lack in maintaining the sexual orientation, which reduces their chances of getting good jobs, political contribution, religious and 
social status. Children of migrant families are deprived of getting education and their health is also affected (UNESCO, 2011). The present study explores the reasons of economic empowerment of women entrepreneurs in the informal sector.

Table: 1

Distribution of respondents according to, are women less paid than men in the informal sector

\begin{tabular}{|l|c|c|}
\hline $\begin{array}{l}\text { Are women less paid than men in } \\
\text { the informal sector }\end{array}$ & Frequency & Percentage \\
\hline Yes & 70 & $70 \%$ \\
\hline No & 30 & $30 \%$ \\
\hline Total & $\mathbf{1 0 0}$ & $\mathbf{1 0 0 \%}$ \\
\hline
\end{tabular}

Data indicates that $70 \%$ of the women are paid less than men in the informal sector. It is a fact that globally women are paid less than men. In Pakistan like other developing countries the largest part of informal work is self-employed and majority of informal workers are women who do not have the market access due to strong patriarchal norms. Usually women are underrepresented in higher positions of employment in the informal sector than men's resulting the gender gap in terms of payment is higher in this sector than the formal sector.

Table: 2

Distribution of the respondents according to, are women aware about the policies and laws regarding women's economic empowerment

\begin{tabular}{|l|c|c|}
\hline $\begin{array}{l}\text { Are women aware about the policies and laws } \\
\text { regarding women's economic empowerment }\end{array}$ & Frequency & Percentage \\
\hline Yes & 15 & $15 \%$ \\
\hline No & 35 & $35 \%$ \\
\hline Total & $\mathbf{1 0 0}$ & $\mathbf{1 0 0} \%$ \\
\hline
\end{tabular}

When asked the women about policies and laws regarding women's economic empowerment $35 \%$ of the respondents said that they are unaware about any such policies and laws. The reason behind is the low literacy rate and the restriction of women's mobility due to patriarchal system which confines them to their houses and as a result they fail to get economic empowerment. 
Table: 3

Distribution of the respondents according to, what household expenses are fulfilled by women working in informal sector

\begin{tabular}{|l|c|c|}
\hline $\begin{array}{l}\text { What household expenses are fulfilled by } \\
\text { women working in informal sector }\end{array}$ & Frequency & Percentage \\
\hline Health and medical expenses & 15 & $15 \%$ \\
\hline Children's education & 15 & $15 \%$ \\
\hline Utility bills & 10 & $10 \%$ \\
\hline Food and grocery & 60 & $60 \%$ \\
\hline Total & $\mathbf{1 0 0}$ & $\mathbf{1 0 0 \%}$ \\
\hline
\end{tabular}

While enquiring women about their household expenses which are fulfilled by their earning $60 \%$ of the respondents said that they spend their earnings for purchasing food and grocery items for their family while $15 \%$ each respondents said that they spend it on their children's education whom they want to be a productive member of the society after getting good education and get respectable job, some of them said that they spend their income on maintaining the health of their family members and bear medical expenditures whereas, $10 \%$ said that they pay their utility bills out of their earning to give relief to their head of the family and to share their burden.

Table: 4

Distribution of respondents according to, what measures are taken by developing countries to enhance the role of women entrepreneurs

\begin{tabular}{|l|c|c|}
\hline $\begin{array}{l}\text { What measures are taken by developing } \\
\text { countries to enhance the role of women } \\
\text { entrepreneurs }\end{array}$ & Frequency & Percentage \\
\hline Better representation of women & 44 & $44 \%$ \\
\hline $\begin{array}{l}\text { Increasing female labour force participation } \\
\text { according to demography }\end{array}$ & 33 & $33 \%$ \\
\hline $\begin{array}{l}\text { Making effective policies for better performing } \\
\text { female-owned enterprises }\end{array}$ & 14 & $14 \%$ \\
\hline Introducing easy micro-finance schemes & 09 & $9 \%$ \\
\hline Total & $\mathbf{1 0 0}$ & $\mathbf{1 0 0 \%}$ \\
\hline
\end{tabular}

When asking them about the measures taken by developing countries to enhance the role of women entrepreneurs data has shown that $44 \%$ of the respondents said they found better representation of women while, 33\% said that there is an increasing female labour force participation according to demography, whereas, in the viewpoint of $14 \%$ respondents that they are making effective policies for 
better performing female-owned enterprises, and $9 \%$ said that they are introducing easy micro-financing schemes for women entrepreneurs.

Table: 5

Distribution of respondents according to, how triple burden effects women's health and family life

\begin{tabular}{|l|c|c|}
\hline $\begin{array}{l}\text { How triple burden effects women's health and } \\
\text { family life }\end{array}$ & Frequency & Percentage \\
\hline Their health is effected & 60 & $60 \%$ \\
\hline Socialization reduces & 20 & $20 \%$ \\
\hline Children get neglected & 14 & $14 \%$ \\
\hline $\begin{array}{l}\text { They suffer from Emotional and psychological } \\
\text { exhaustion }\end{array}$ & 06 & $6 \%$ \\
\hline Total & $\mathbf{1 0 0}$ & $\mathbf{1 0 0 \%}$ \\
\hline
\end{tabular}

While responding the question about how triple burden effects women's health and family life $60 \%$ of the respondents said that their health is effected due to triple burden, $20 \%$ replied that their day today socialization reduces due to their work, while $14 \%$ women said that their children get neglected due to their triple burden, and $6 \%$ said that they suffer from emotional and psychological exhaustion due to the role they are playing for the survival of their family.

Table: 6

Distribution of respondents according to, do women face more discrimination than men in informal sector

\begin{tabular}{|l|c|c|}
\hline $\begin{array}{l}\text { Do women face more discrimination than } \\
\text { men in informal sector }\end{array}$ & Frequency & Percentage \\
\hline Yes & 65 & $65 \%$ \\
\hline No & 35 & $35 \%$ \\
\hline Total & $\mathbf{1 0 0}$ & $\mathbf{1 0 0 \%}$ \\
\hline
\end{tabular}

According to this table $65 \%$ of the respondents said that they are facing more discrimination than men in informal sector, and 35\% said that they are not facing any such discrimination. Women face discrimination regarding low wages, unequal opportunities and low social status. 
Table: 7

Distribution of respondents according to, what are the factors involved in increasing urbanization trend and women incorporation in informal sector

\begin{tabular}{|l|c|c|}
\hline $\begin{array}{l}\text { What are the factors involved in increasing } \\
\text { urbanization trend and women incorporation } \\
\text { in informal sector }\end{array}$ & Frequency & Percentage \\
\hline Poverty & 40 & $40 \%$ \\
\hline Lack of income generating opportunities & 15 & $15 \%$ \\
\hline Illiteracy & 20 & $20 \%$ \\
\hline High inflation rate & 25 & $25 \%$ \\
\hline Total & $\mathbf{1 0 0}$ & $\mathbf{1 0 0 \%}$ \\
\hline
\end{tabular}

Data indicate the factors involved in increasing urbanization trend and women incorporation in informal sector. According to $40 \%$ respondent's poverty is the main cause, while $25 \%$ said that high rate of inflation forced incorporation in informal sector, whereas, $20 \%$ respondents said that due to illiteracy women are incorporated more in informal sector because they have no other choice, and $15 \%$ respondents said that lack of income generating opportunities forced women to join informal sector for earning their bread and butter and to meet their day to day expenses in this growing high inflation rate.

Table: 8

Distribution of respondents according to, what are the barriers in improving women's financial status in informal sector even after having experience and skills

\begin{tabular}{|l|c|c|}
\hline $\begin{array}{l}\text { What are the barriers in improving } \\
\text { women's financial status in informal sector } \\
\text { even after having experience and skills }\end{array}$ & Frequency & Percentage \\
\hline Illiteracy & 40 & $40 \%$ \\
\hline Lack of access to market & 30 & $30 \%$ \\
\hline Low awareness about market trends & 20 & $20 \%$ \\
\hline Gender discrimination & 10 & $10 \%$ \\
\hline Total & $\mathbf{1 0 0}$ & $\mathbf{1 0 0 \%}$ \\
\hline
\end{tabular}

According to this table respondent's identifies some of the barriers which create hurdles in improving women's financial status in informal sector even after having experience and skills. As data shows that $40 \%$ of the respondents said that illiteracy is the biggest barrier in improving the women's financial status, while $30 \%$ said that lack of access to market, whereas, $20 \%$ said that low awareness about market trends also create problems, and $10 \%$ respondents said that gender discrimination also affects them. 
Table: 9

Distribution of respondents according to, what are the reasons of reducing women's efficiency and working capacity

\begin{tabular}{|l|c|c|}
\hline $\begin{array}{l}\text { What are the reasons of reducing women's } \\
\text { efficiency and working capacity }\end{array}$ & Frequency & Percentage \\
\hline Low social status & 50 & $50 \%$ \\
\hline Cultural constraints & 30 & $30 \%$ \\
\hline $\begin{array}{l}\text { No access to practical gender needs and } \\
\text { strategic gender needs }\end{array}$ & 10 & $10 \%$ \\
\hline $\begin{array}{l}\text { Limited mobility and limited access to human } \\
\text { rights and labour laws }\end{array}$ & 10 & $10 \%$ \\
\hline Total & $\mathbf{1 0 0}$ & $\mathbf{1 0 0 \%}$ \\
\hline
\end{tabular}

Data indicates the reasons of reducing women's efficiency and working capacity $50 \%$ of the respondents said that their efficiency and working capacity affects due to their low social status, while $30 \%$ respondents said that cultural restraints also affects their efficiency and working capacity, whereas, $10 \%$ each said that limited mobility and limited access to human rights and labour laws, no access to practical gender needs and strategic gender needs also badly affects their efficiency and working capacity.

Table -10

Distribution of respondents according to, what steps are taken by the government of Pakistan to give economic empowerment to women

\begin{tabular}{|l|c|c|}
\hline $\begin{array}{l}\text { What steps are taken by the government of } \\
\text { Pakistan to give economic empowerment to women }\end{array}$ & Frequency & Percentage \\
\hline Micro-Finance schemes are introduced & 05 & $5 \%$ \\
\hline $\begin{array}{l}\text { Workshops and seminars are organized at national } \\
\text { level }\end{array}$ & 05 & $5 \%$ \\
\hline Establishing organizations like SMEDA & 20 & $20 \%$ \\
\hline Maintaining gender equality & 10 & $10 \%$ \\
\hline Equal access to resources & 10 & $10 \%$ \\
\hline Including women in mainstream development & 40 & $40 \%$ \\
\hline Protection of rights of women & 10 & $10 \%$ \\
\hline Total & $\mathbf{1 0 0}$ & $\mathbf{1 0 0 \%}$ \\
\hline
\end{tabular}

While telling about the steps taken by the government of Pakistan to give economic empowerment to women $40 \%$ of the respondents said that they are including women in mainstream development by making some effective policies, $20 \%$ said that government is establishing organizations like SMEDA which help and support women entrepreneurs, while $10 \%$ each said that government is trying to maintain gender equality, and trying to provide equal access to resources to 
women, and making laws for the protection of rights of women, while 5\%each said that Micro-Finance schemes are introduced for women to provide them financial assistance for establishing their own business, and also arranging workshops and seminars at national level to give awareness to women entrepreneurs regarding their business.

\section{Conclusions}

This research reflects the socio-economic problems of women entrepreneurs along with their economic empowerment in the informal sector. This study also caters other aspects like their wage issues in comparison to men. Usually these women focus to manage household expenses to meet the day to day needs. Women face triple burden, but they still manage to increase their family income. Since informal sector is the backbone of national economy therefore, government should facilitate them by formulating effective policies. Developed nations have realized the importance of entrepreneurship and women workers in the informal sector, which has given boost to their national economy. Similarly, developing nation should also focus this sector to promote women workers and entrepreneurship, so that they can play their role efficiently and can be equally useful like men in the developing process.

The research also focuses on recognizing the role of women entrepreneurs in informal sector for their economic empowerment. Since economic, political and empowered role of women has become a very focal point, therefore, it is needed to explore all the aspects which restrict them from gaining independent and decisive life. This research aims to highlight the social biasness and gender discrimination, which marginalize women from doing things independently. Class difference and unequal distribution of power and resources definitely reduces their efficiency.

\section{Recommendations}

1. Women entrepreneurs must be provided training on professional level in order to make them more skilled and productive.

2. Government has a very important role to promote the work of women entrepreneurs without the involvement of a middle-man.

3. The products manufactured by these women should be exhibited in a bigger market by the Government and private organizations.

4. Small financing schemes should be introduced to provide easy access to women entrepreneurs in order to provide easy loan and financial support.

5. Government should maintain the record of entrepreneurship in order to bring these women in mainstream of economy.

6. Government should formulate effective policies with proper 
implementation to give easy access at all levels in terms of raw material, loans and their profit margins.

\section{References}

Bertulfo, Lota. Women and the informal economy: A think piece, Australia, Office of Development Effectiveness. (November, 2011). Retrieved on April $22^{\text {nd }} 2016$ https:/dfat.gov.au/aid/how-we-measure-performance/ode/Documents/ women-informal-economy-lota-bertulfo.pdf

Chatterjee, Chandrima B. \& Gunjan Sheoran (2007). Vulnerable Groups in India. Mumbai: Centre for Enquiry into Health and Allied Themes.

Chen, Martha Alter. "Women and Informality: A Global Picture, the Global Movement." SAIS Review 21, No. 1 (2001): 71-82. Retrieved on April $30^{\text {th }}, 2016$ http://info.worldbank.org/etools/docs/library/76309/dc2002/ proceedings/pdfpaper/module6mc.pdf

Doane, Donna L. (2007). Living in the Background: Home-Based Women Workers and Poverty Persistence. [Manchester]: Chronic Poverty Research Centre.

Farah, N. R. (2009). Egypt's political economy: Power relations in development. Cairo: American University in Cairo Press, p. 129.

Ghosh, B. N. (2015). Contemporary Issues in Development Economics, USA, Taylor \& Francis, p.61.

Hassan, Syeda Mahnaz \& Farooq, Fatima. "Gendered Perspective of Informal Sector of the Economy in Pakistan", Pakistan Journal of Commerce and Social Sciences, Vol. 9 (1), 2015. PP. 185-201.

Hindman, H. D. (2015). The world of child labor: An historical and regional survey, London, Routledge, p. 841.

Homebased_Workers, HomeNet South Asia (HNSA) Available at, http://www.homenetsouthasia.net/Issues_of_Homebased_Workers.html (June 3, 2014). P. 1.

ILO. Zambian Women Entrepreneurs: Going For Growth, Geneva, ILO, 2003. International Labour Office (ILO). Women and Men in the Informal Economy: A Statistical Picture (second edition), Geneva: ILO. (2013). Retrieved on April 28 ${ }^{\text {th }}, 2016$. 
International Labour Office. Women and Men in the Informal Economy A Statistical Picture. Geneva: International Labour Office, 2014.

International Labour Office. Women, Gender and the Informal Economy: An Assessment of ILO Research and Suggested Ways Forward. Geneva: ILO, 2008.

Khan, Tasmeena \& Khan, Rana Ejaz Ali. (2009). "Urban Informal Sector: How Much Women Are Struggling for Family Survival." The Pakistan Development Review, vol.48:1, pp.67-95.

Konayuma, G. Challenges of Shrinking Informal Sector in Africa and the Need to Strengthen Entrepreneurship Training: The Case Study of Zambia, Paper presented at the Commonwealth conference on Association of Polytechnics in Africa, Livingstone, 2006.

Leonard, T. M. (2006). Encyclopedia of the developing world: Index, London, Routledge, p. 1311.

Mahtab, N. et. al (2018). Handbook of research on women's issues and rights in the developing world, Bangladesh, IGI Global, p.133.

Maxwell, D., Levin, C. \& Armar-Klemesu, M. (2000). Urban livelihoods and food and nutrition security in greater Accra, Ghana, Washington, D.C, International Food Policy Research Institute, p. 28.

Mbeche. Factors Affecting the Performance of Women Entrepreneurs in Micro and Small Enterprises: The Case of Dessie Town. New Delhi, IN.: Educational Planning and Management Department, 2010.

Memon, R. Determinants and trends of international migration in Pakistan, In H. Oda (Ed.), International Labor Migration in Pakistan, Tokyo: Institute of Developing Economies, Japan External Trade Organization, 2006.

Mohapatra, Kamala Kanta. Women Workers in Informal Sector in India: Understanding the Occupational Vulnerability, International Journal of Humanities and Social Science, Vol. 2(21), Nov. 2012. PP. 197-207.

Mwaba, Karen. The Informal Economy and Entrepreneurship Training in Zambia Can It Lead to the Empowerment of Women? Rotterdam: Erasmus University, 2010.

Organisation de coopération et de développement économiques,. (2012). The future of families to 2030, Paris, OCDE, p. 78. 
Ramani, Shyama V., Thutupalli, Ajay, Medovarszki, Tamás, Chattopadhyay, Sutapa and Ravichandran,Veena. Women in the Informal Economy: Experiments in Governance from Emerging Countries, United Nations University: UNU-MERIT, 2013.

Reeves, H. and Baden, S. Gender \& Development: Concepts and Definitions, University of Sussex, BRIDGE, 2000, p. 35.

Richardson, P. \& Finnegan, G. (2004). The Challenges of Growing Small Businesses: insights from Women Entrepreneurs in Africa, Geneva, ILO.

Saigol, R. (2010). The Informal Sector, Social Protection and the Budget. HomeNet Pakistan, p.1.

Stromquist, N. P. (2014). Women in the third world: An encyclopedia of contemporary issues, Hoboken, Routledge, Taylor and Francis, p. 195.

Sudarshan, R. M. \& Sinha, S. (2011). Making Home-Based Work Visible: A Review of Evidence from South Asia. Women in Informal Employment: Globalizing and Organizing (WIEGO) Urban Policies Research Report, (10).

Sudharshan, R. N. \& Jhabyala, R. (2006). Social Protection for Homebased Women Workers in South Asia: Learning from Action and Research. Home Net South Asia and Institute of Social Studies Trust (ISST).

Taib, Muhammad Naseer Ahamd. (2014). Psycho-Social Problems of Female Entrepreneurs in Pakistan: An Analysis, Journal of Professional Research in Social Sciences (JPRSS), Vol. 1(1), pp.47-55.

UNESCO. Internal Migration http://www.unesco.org/new/en/newdelhi/areas-of action/ social-and-human-sciences/internal-migration/, 2011.

Seema Manzoor is Lecturer in the Centre of Excellence for Women's Studies, University of Karachi.

Dr. Asma Manzoor is an Assistant Professor in the Centre of Excellence for Women's Studies, University of Karachi.

Dr. Misbah B. Qureshi is Professor and Director in the Institute of Gender Studies, Sindh University Jamshoro. 